\title{
Anther smuts on Butterworts (Pinguicula spp.)
}

\author{
Paul A. Smith ${ }^{1}$, Matthias Lutz ${ }^{2}$, Arthur O. Chater ${ }^{3}$ \& Ray G. Woods ${ }^{4}$
}

\begin{abstract}
Microbotryum pinguiculae has recently been reported from Wales as new to Britain, and we present details of locations and infection rates, and also report a first record for Scotland. We expand previous molecular phylogenetic analyses to include a specimen from Wales, and also examine specimens from Austria infecting Pinguicula leptoceras. All these new collections are referable to $M$. pinguiculae s.str., demonstrating that this smut species can infect these two closely-related host species.
\end{abstract}

\section{Introduction}

Smut species in the genus Microbotryum infect a rage of different plant organs (Kemler et al. 2020). There is a particularly wide range of cryptic species found in the anthers of different host plants, many of which are in the Caryophyllaceae. But a recent paper (Ziegler et al. 2018) focussed on the anther smuts in butterworts (Pinguicula spp.), which have previously been found to be quite distantly related to anther smuts infecting Caryophyllaceae (Lutz et al. 2005; Kemler et al. 2006, 2009). Ziegler et al. (2018) considered specimens from three host species, Pinguicula alpina L., P. villosa L. and $P$. vulgaris $L$. and discovered that each supported a different segregate of Microbotryum. P. vulgaris is the type host of M. pinguiculae (Rostr.) Vánky, a name which had hitherto been used as a catch-all for anther smuts on Pinguicula spp. The smut on $P$. alpina was described as M. alpinum R. Ziegler, M. Lutz \& Piątek, and that on P. villosa as M. liroi R. Ziegler, M. Lutz \& Piątek, separating them into three species.

\section{M. pinguiculae in Britain and Ireland}

In Britain and Ireland there are three native Pinguicula species: P. lusitanica L. and $P$. vulgaris are relatively widepread, and $P$. grandiflora Lam. is restricted to southern Ireland. There were no records for M. pinguiculae s.l. in the Fungus Records Database of Britain and Ireland (FRDBI), and the species is not included in Legon \& Henrici (2005) or its updates until update 9 (Ainsworth \& Henrici 2020), so seemed to be previously unknown in Britain. However, the Biological flora of the British Isles account of Pinguicula (Heslop Harrison 2004) says that "The anthers of $P$. vulgaris are attacked by Ustilago pinguiculae Rostrup in Europe [...]; a brownish discoloration of the anthers has sometimes been observed in British plants, perhaps also owing to this infection", so it seems that it has previously been suspected to be present in Britain, if not formally recorded.

Setting this as a challenge for the Welsh Rust Group led very quickly to its discovery by RGW at Pentrosfa Mire, vc43 (see table 1 for full details) on $P$. vulgaris, apparently the first formal record for Britain (Woods et al. 2018). The spore deposit of $M$. pinguiculae is pale violet (or brownish violet) as described by Ziegler et al. (2018), but in some specimens can appear more brown because of the purple colour of the corolla (Fig. 1). Detailed spore pictures are available in Ziegler et al. (2018).

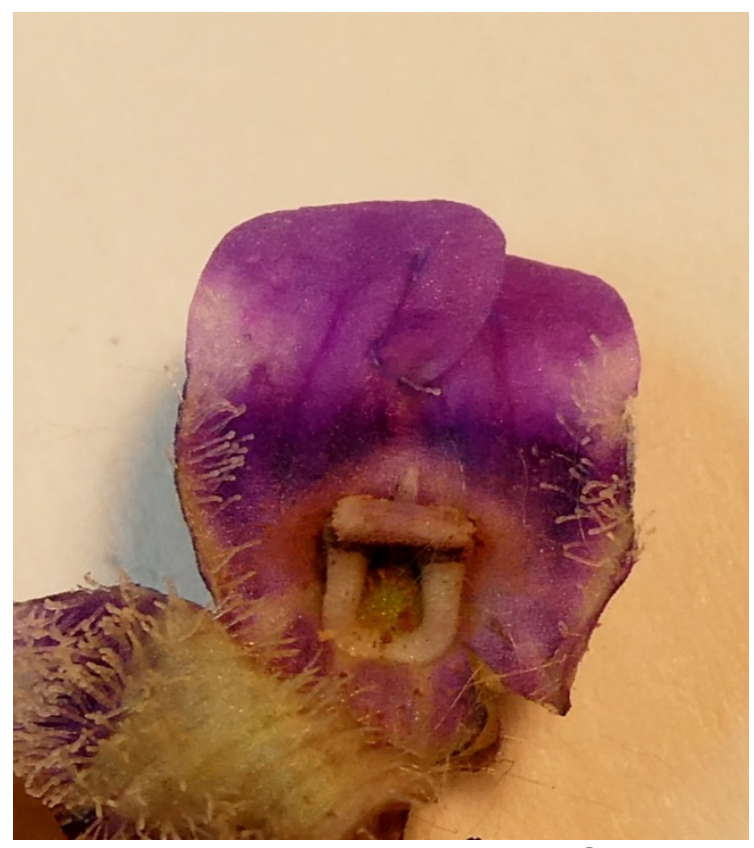

(C) RG Woods

Fig. 1. Brownish tinged spores of $M$. pinguiculae; Pentrosfa Mire (see Table 1 for full details). 


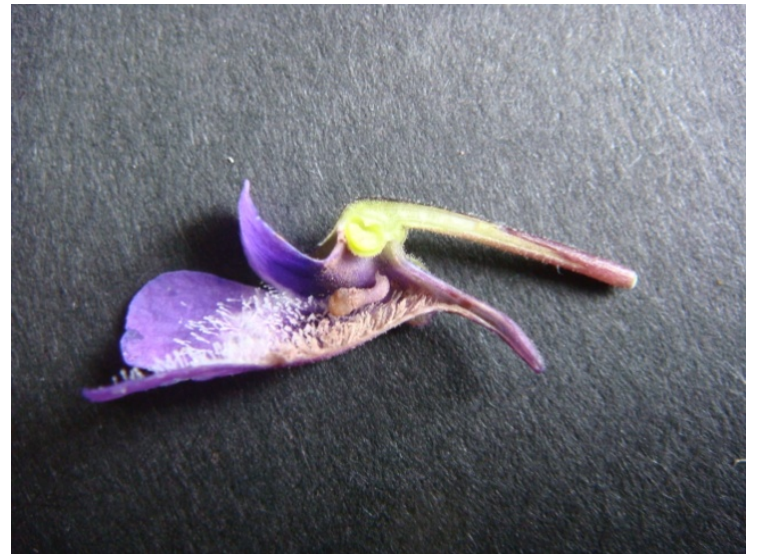

(C) AO Chater

Fig. 2(a). Longitudinal section through infected flower showing the way the infected anthers are hidden. Flush on moorland slope $3.5 \mathrm{~km} \mathrm{E}$ of Ffair-rhos, Ceredigion, SN773680, 400 m, 1 June 2018.

The main challenge in detecting the infection is that the throat of the corolla is very closed in Pinguicula vulgaris, in contrast to $P$. alpina, so that it is necessary to pull the corolla apart to see the discoloured anthers inside (Fig. 2).

Some infected flowers have the upper lip somewhat contorted, which narrows the entrance to the flower even further (Fig. 3; Woods et al. 2018, p41).

M. pinguiculae has now been found from several sites in Wales (Fig. 4). Woods et al. (2018) reported high rates of population infection, and high rates of infection within infected populations, and Fig. 3 shows the proportions of each population examined that were infected. Some of these populations of

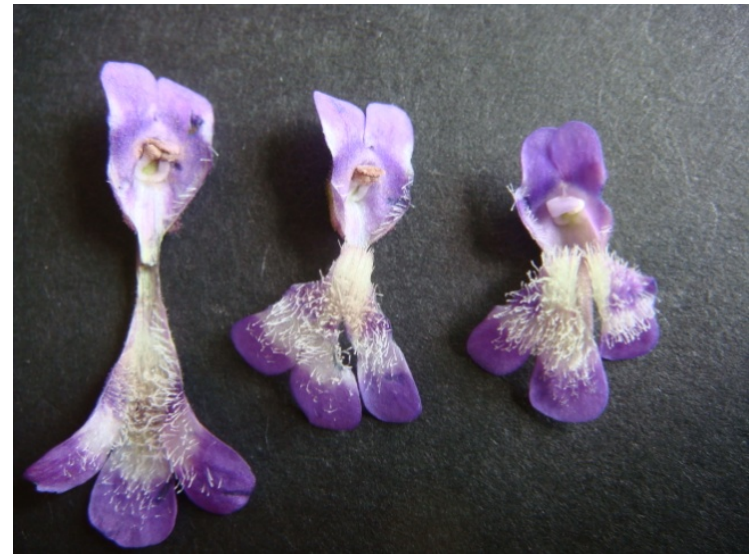

(C) AO Chater

Fig. 2(b). Two corollas (left) pulled apart to expose the infected anthers; an uninfected flower is shown on the right. Flush on moorland slope, Bryn Lluestydd, $6 \mathrm{~km}$ E of Tal-ybont, Ceredigion, SN718896, 350 m, 2 June 2018.

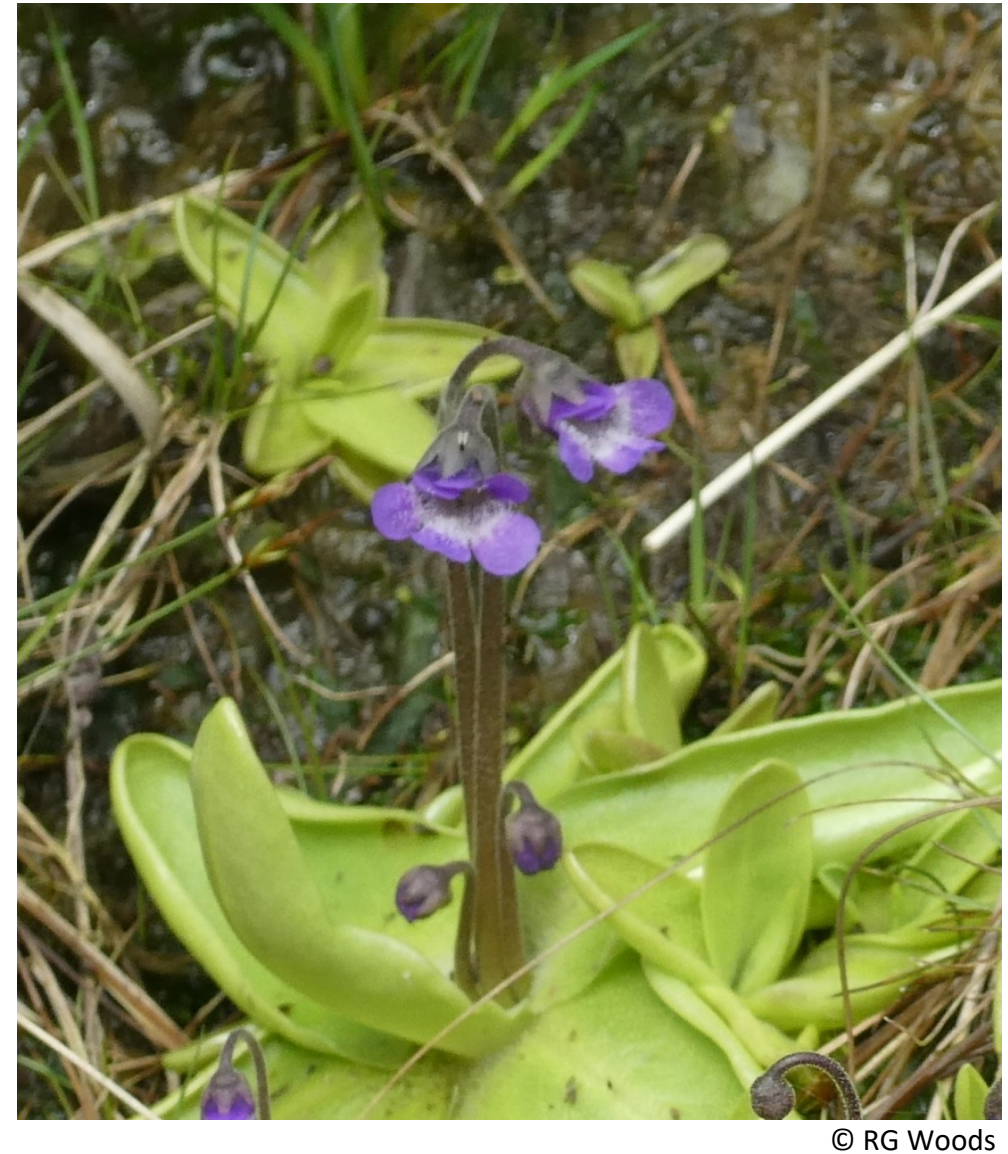

Fig. 3. Infected flowers of $P$. vulgaris showing the somewhat flattened corollas.

Pinguicula vulgaris were tiny,

so the percentages are only very crude approximations, but they do demonstrate that the infected plants were in the majority in many populations. Many populations of Pinguicula vulgaris are relatively isolated from each other, so the question of how the smut may be transmitted between 
them is an open one. Heslop-Harrison (2004) says that they are pollinated by bees, but it is still unlikely for a single bee to transfer spores between separated populations.

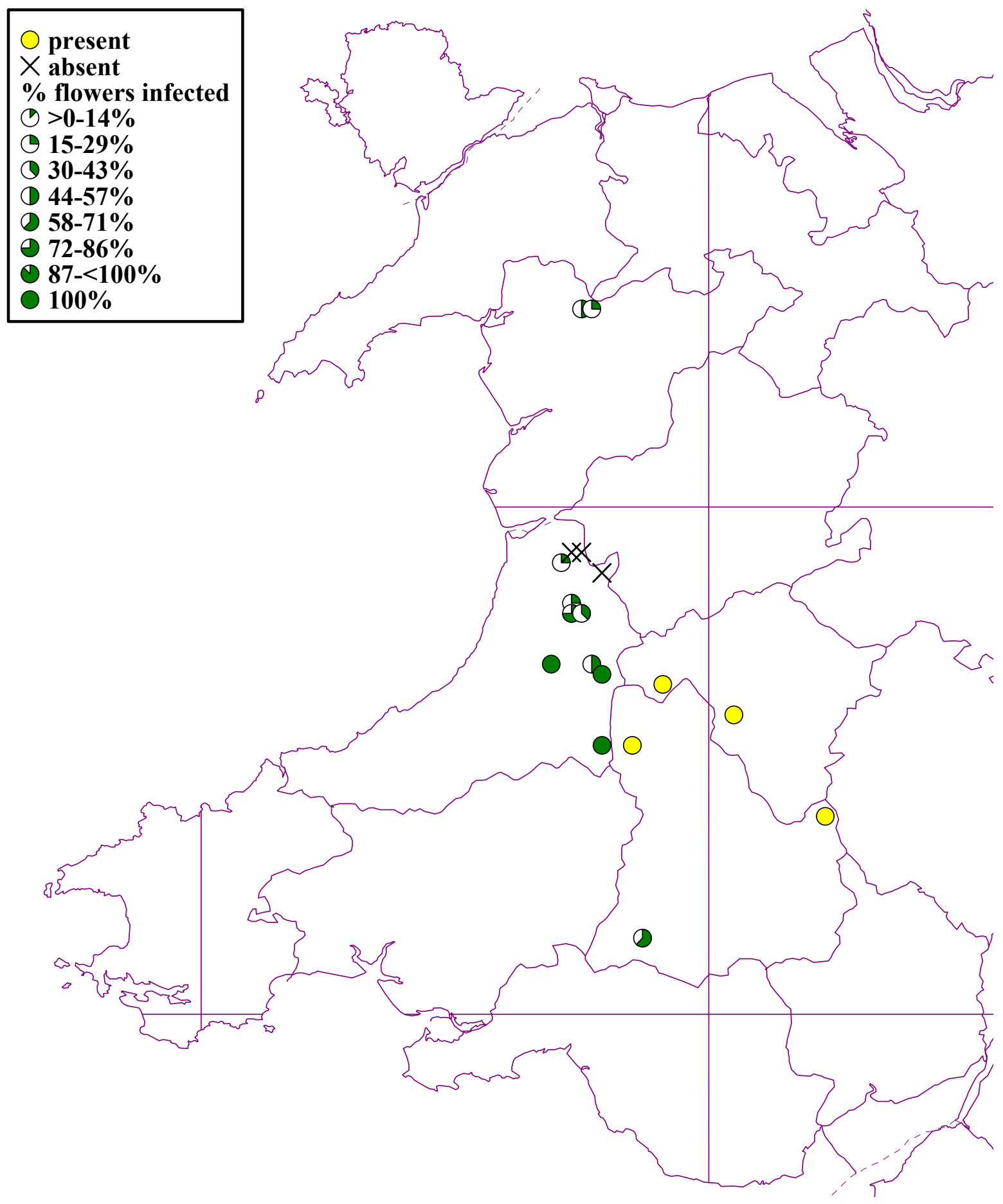

Fig. 4. Distribution of Microbotryum pinguiculae in Wales, and (where recorded) infection rates of examined populations of Pinguicula vulgaris.

Even within a population it is interesting to consider how $M$. pinguiculae persists. Schellenberg (1911) observe that all the flowers on a single plant are infected, and that the same stock produces infected flowers in all years, and therefore concludes that the mycelium is systemic in the stock; Lind (1913) also says that the infection is systemic. AOC found several flies well within the flowers of an uninfected population of $P$. vulgaris on Pumlumon, above Llyn Llygad Rheidol (600 m altitude), vc46. These were determined by Mike Howe as Empis verralli Collin, a relatively widespread species. These 
are potentially vectors for within population transfer of infections, but not likely to effect exchange between populations.

Pinguicula vulgaris is an early-flowering species, but some finds have been made slightly later in the season from corollas still attached to the stem. Krieglsteiner (2002) discovered Microbotryum pinguiculae at Sippenauer Moor in Germany in late June and commented that the only flowering plants were infected ones. So the smut may extend or delay the flowering period. But this does not seem a useful adaptation to dispersal by insect pollination.

The effect of the smut on seed production in its host is also interesting. From visits to Pentrosfa Mire it seems that infected flowers (which are rendered male sterile) do not set seed. Some populations in Cardiganshire appeared to be in decline, though this could be for reasons unconnected with infection by M. pinguiculae. Nordin (2015) found similarly high rates of infection and low rates of seed set for M. alpinum on Pinguicula alpina in Gotland.

Karlsson et al. (1990) study resource allocation in reproduction in Pinguicula alpina, $P$. villosa and $P$. vulgaris. They discover that only small proportions of plants flower in any year and suggest that "it is possible that the low flowering frequency in Pinguicula is an adaptation to avoid diseases or pathogens coupled to the reproductive cycle," and mentioning M. pinguiculae (as Ustilago). Some examination of the population dynamics of Microbotryum smuts and their hosts would be valuable.

\begin{tabular}{|c|c|c|c|}
\hline Host & Country & $\begin{array}{l}\text { GenBank accession nos. } \\
\text { (ITS/28S) }\end{array}$ & Collection details \\
\hline Pinguicula leptoceras & Austria & MT663526/MT663522 & $\begin{array}{l}\text { Tirol, Ötztal, Vent, Quellflur } \\
\text { north of the village, } \\
46^{\circ} 51^{\prime} 58.32^{\prime \prime N} \\
10^{\circ} 54^{\prime} 55.41^{\prime \prime} \mathrm{E} \text {, ca. } 1970 \mathrm{~m} \\
\text { asl., } 23 \text { June } 2018 \text {, leg. H. } \\
\text { Fischer \& M. Lutz, KR-M- } \\
0005958\end{array}$ \\
\hline Pinguicula leptoceras & Austria & MT663527/MT663523 & 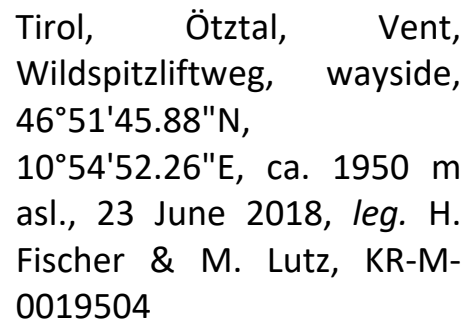 \\
\hline (1) & Austria & MT663529/MT663525 & $\begin{array}{l}\text { Tirol, Ötztal, Vent, street to } \\
\text { Rofen, roadside, } \\
46^{\circ} 51^{\prime} 27.01^{\prime \prime N}, \\
10^{\circ} 54^{\prime} 25.02^{\prime E} \text {, ca. } 1985 \mathrm{~m}, \\
23 \text { June } 2018 \text {, leg. H. Fischer } \\
\text { \& M. Lutz, KR-M-0019505 }\end{array}$ \\
\hline Pinguicula vulgaris & UK & MT663528/MT663524 & $\begin{array}{l}\text { Pentrosfa Mire, Llandrindod } \\
\text { Wells, vc43, SO059597, } 30 \\
\text { May 2018, leg. R.G. Woods, } \\
\text { KR-M-0019510 }\end{array}$ \\
\hline
\end{tabular}

Table 1. Specimens used in this study, additional to those in Ziegler et al. (2018). Accession numbers are for mycological herbarium of the Staatliches Museum für Naturkunde Karlsruhe (KR-M). 


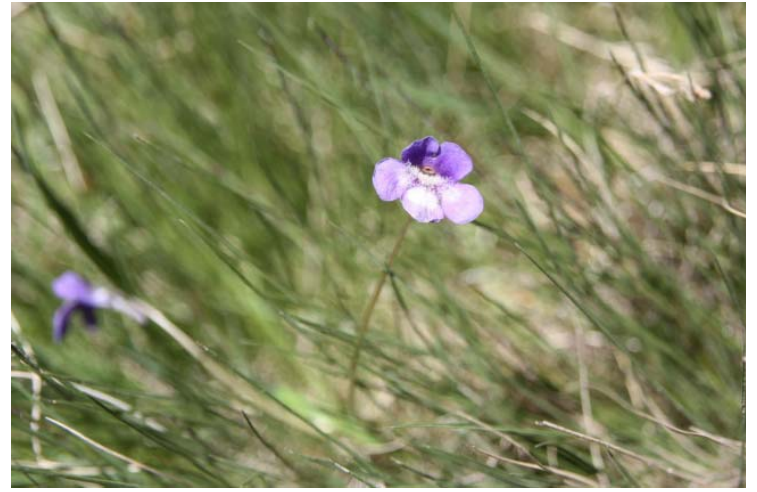

(c) M Lutz

Fig. 5(a). Infected flower of $P$. leptoceras in situ.

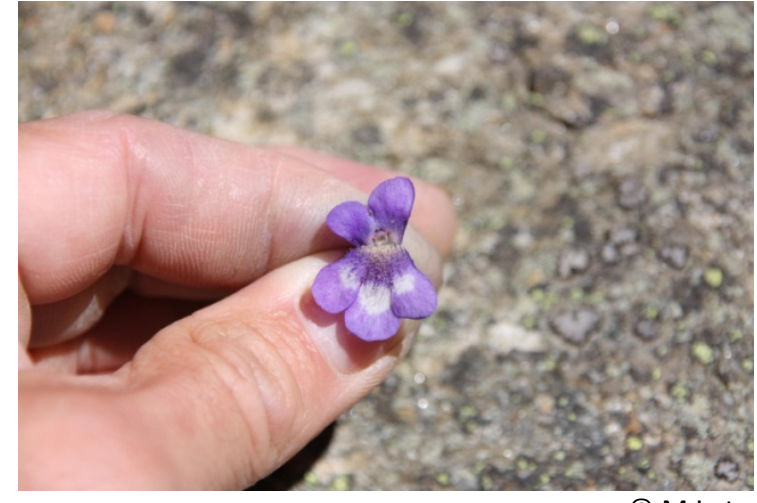

(c) M Lutz

Fig. 5(b). Infected flower of $P$. leptoceras showing the swollen anthers and spores.

PAS found M. pinguiculae on P. vulgaris in Scotland in 2019 (at Loch Ashie, vc96, NH6234 and NH631357, 25 June 2019), and a first formal record for England has recently appeared on the web at https://www.inaturalist.org/observations/47569365. So far, we know of no reports of infections on the other species of Pinguicula which are found in Britain and Ireland. P. Iusitanica is quite distantly related to all the other species considered in this paper, but $P$. grandiflora is in the same clade as the other hosts considered here (Degtjareva et al. 2006).

\section{Molecular phylogenetic analysis of anther smuts on Pinguicula leptoceras and $\boldsymbol{P}$. vulgaris}

Meanwhile, ML managed to collect some further infected Pinguicula plants, this time of $P$. leptoceras Rchb., from a cluster of three sites near to each other in Austria (Fig. 5a \& b). The ITS and $28 \mathrm{~S}$ D1/D2 sequences were extracted from these collections and from a specimen from the firstdiscovered Welsh site at Pentrosfa Mire (collection details and GenBank sequence accession numbers are given in Table 1). The concatenated sequences were used in a phylogenetic analysis alongside the specimens previously analysed by Ziegler et al. (2018), and using the same methods (which are therefore not redescribed here). The tree was rooted with Microbotryum betonicae (Beck) R. Bauer \& Oberw. 


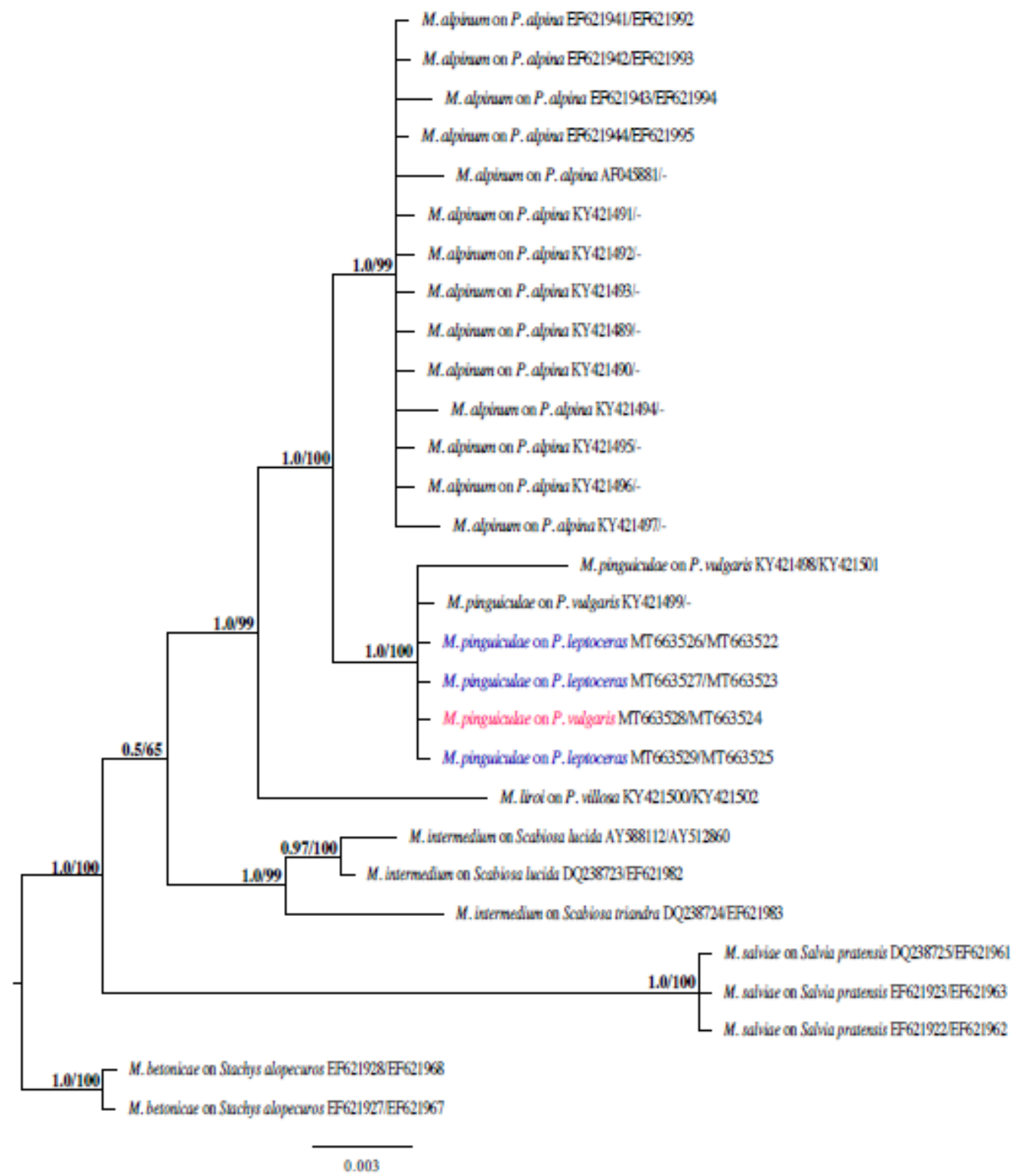

Fig. 6. Bayesian inference of phylogenetic relationships within the sampled Microbotryum species. Markov chain Monte Carlo analysis of an alignment of concatenated ITS+28S sequences using the GTR+I+G model of DNA substitution with gamma distributed substitution rates and an estimated proportion of invariant sites, random starting trees, and default starting parameters of the DNA substitution model. A 50\% majority-rule consensus tree is shown computed from 75000 trees that were sampled after the process had become stationary. The topology was rooted with Microbotryum betonicae. Numbers on branches before slashes are estimates for a posteriori probabilities; numbers on branches after slashes are ML bootstrap support values. Branch lengths were averaged over the sampled trees. They are scaled in terms of expected numbers of nucleotide substitutions per site. M. = Microbotryum; $P$. = Pinguicula. The new specimens in this study are shown in blue (on P. leptoceras) and pink (on P. vulgaris).

A phylogenetic hypothesis is shown in Fig. 6. All the new specimens show both identical ITS and 28S sequences and cluster closely with the previously sequenced collections of $M$. pinguiculae s.str. The differences between the new specimens from $P$. leptoceras and $P$. vulgaris and the two specimens avaialble in Genbank (both from P. vulgaris: STU 10004567401, KY421498/KY421501 (ITS/28S), Germany; GLM 046919, KY421499 (ITS), Austria) are small (ITS: 1 bp, 28S: 5 bp), and the presented consensus tree as well as the ITS and $28 \mathrm{~S}$ data suggest that the anther smut on the two different 
host plant species are not differentiated on the basis of the genes considered. We infer that $M$. pinguiculae is a species capable of infecting multiple closely-related species in the genus Pinguicula. Therefore $P$. leptoceras can be added to the account of Ziegler et al. (2018) as a further host species, and the UK can be added to the known distribution of $M$. pinguiculae.

These relationships amongst infections on Pinguicula spp. closely mirror relationships within the host family itself. Degtjareva et al. (2006) show that $P$. leptoceras and $P$. vulgaris are closely related within the same clade within Pinguicula, and that $P$. alpina and $P$. villosa are both distantly related, falling in separate clades. This is one of many examples of parasitic fungi acting as plant taxonomists (e.g., Savile 1954, Kukkonen \& Timonen 1979).

\section{European distribution}

M. pinguiculae was separated from Ustilago violacea s.I. by Rostrup in 1890, and there was a period at the end of the $19^{\text {th }}$ century when it was frequently recorded. This was followed by a period when it was either forgotten or became unfashionable, and there were relatively few records. An upsurge in modern records is associated with the description of new species. The European distributions of species on hosts dealt with here and by Ziegler et al. (2018) are shown in Fig. 7. M. alpina seems to infect $P$. alpina throughout its range (as summarised by Casper 1972), and $M$. liroi similarly seems to have been recorded across the range of $P$. villosa. $P$. vulgaris, however, the most widely distributed species in the genus in Europe (Casper 1972) has not been recorded as infected across its range. Indeed several authors have commented that they did not find it while specifically searching (e.g., Liro 1924, Kemler et al. 2005). In contrast, the recent (formal) discovery in Britain, and the relatively high rate of finds among the searched populations, suggests that it awaits discovery in other places in the range of $P$. vulgaris. Further targeted searching is needed to expand our knowledge of the distribution of $M$. pinguiculae.

\section{Conclusions}

It seems that $M$. pinguiculae will prove to be widespread in Britain, and is potentially present elsewhere in Europe, and we encourage micromycologists to actively search for it - it is very unlikely to be discovered by casual observation. There are several aspects of the ecology and life history of $M$. pinguiculae which seem to be unknown, and which would benefit from some observational research. And there is plenty of scope for examination of further relationships within Microbotryum taxa on Pinguicula spp. - Ziegler et al. (2018) list several other species from which M. pinguiculae has been reported. We would be interested to hear of infections on any other species of Pinguicula.

\section{Acknowledgements}

We are grateful to Gethin Elias and Julian Woodman who made collections of infected material. 


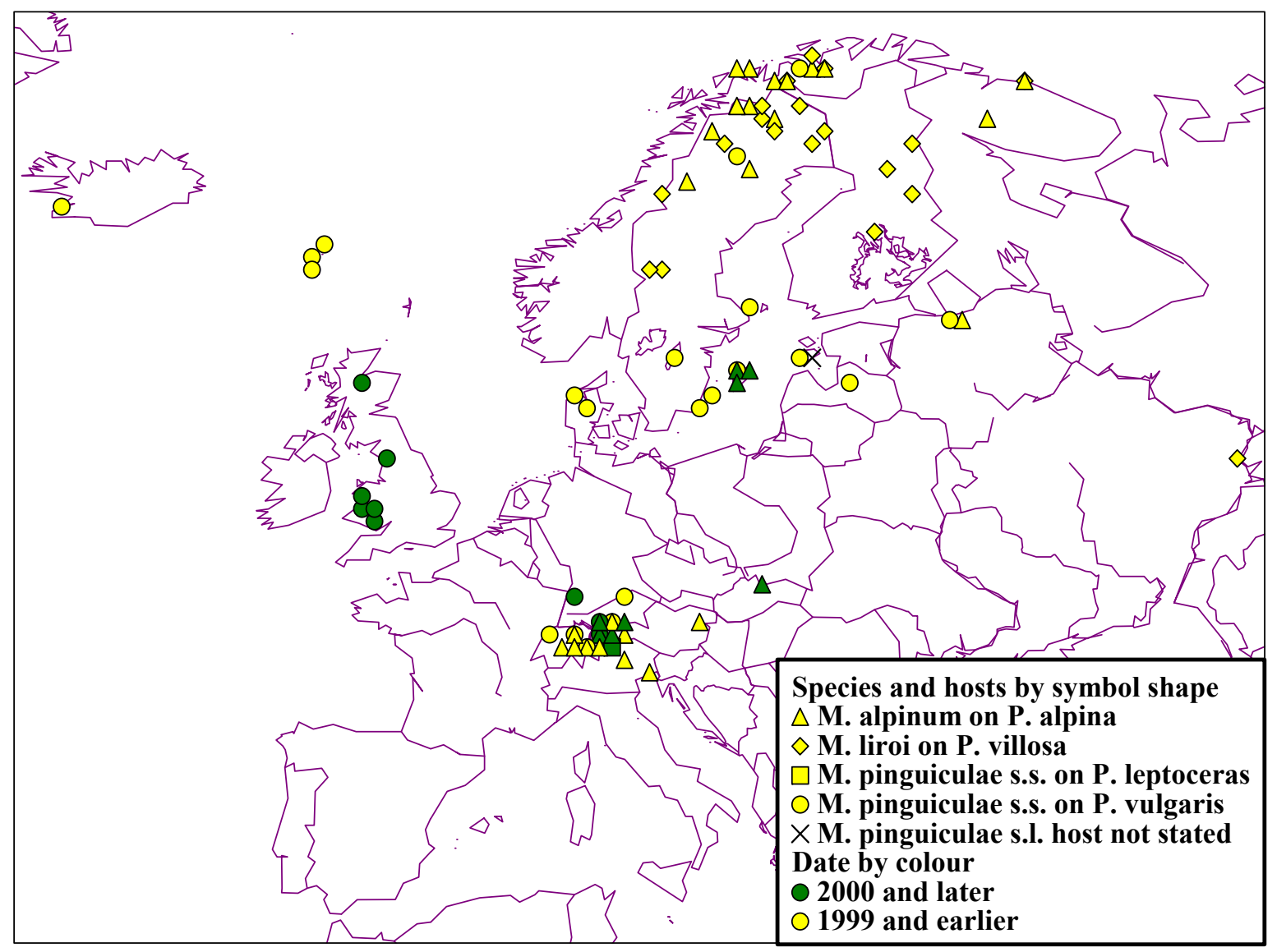

Fig. 7. European distributions of Microbotryum spp. on Pinguicula spp. covered in this paper and in Ziegler et al. (2018), based on published and web-accessible records. Symbols indicate one or more records in a $30^{\prime} \times 45^{\prime}$ square. Note that some symbols are superimposed. Map produced with DMAP.

\section{References}

Ainsworth, A.M. \& Henrici, A. (2020) CBIB ninth update (UD9). http://www.basidiochecklist.info/ Updates/Update9\%202020Feb\%20to\%20IT\%2026Feb2020.pdf.

Casper, S.J. (1972). Pinguicula L. In Tutin, T.G., Heywood, V.H., Burges, N.A., Moore. D.M., Valentine, D.H., Walters, S.M. \& Webb, D.A. (eds) Flora Europaea, vol. 3, pp. 294-296. Cambridge University Press, Cambridge.

Degtjareva, G.V., Casper, S.J., Hellwig, F.H., Schmidt, A.R., Steiger, J. \& Sokoloff, D.D. (2006). Morphology and nrITS phylogeny of the genus Pinguicula L. (Lentibulariaceae), with special attention to embryo evolution. Plant Biology 8: 778-790.

Heslop-Harrison, Y. (2004). Pinguicula L. Journal of Ecology 92: 1071-1118.

Karlsson, P.S., Svensson, B.M., Carlsson, B.Å. \& Nordell, K.O. (1990). Resource investment in reproduction and its consequences in three Pinguicula species. Oikos 59: 393-398.

Kemler, M., Denchev, T.T., Denchev, C.M., Begerow, D., Piątek, M. \& Lutz, M. (2020). Host preference and sorus location correlate with parasite phylogeny in the smut fungal genus Microbotryum (Basidiomycota, Microbotryales). Mycological Progress 19: 481-493.

Kemler, M., Göker, M., Oberwinkler, F. \& Begerow, D. (2006). Implications of molecular characters for the phylogeny of the Microbotryaceae (Basidiomycota: Urediniomycetes). BMC Evolutionary Biology 6: 35. 
Kemler, M., Lutz, M., Göker, M., Oberwinkler, F. \& Begerow, D. (2009). Hidden diversity in the noncaryophyllaceous plant-parasitic members of Microbotryum (Pucciniomycotina: Microbotryales). Systematics and Biodiversity 7: 297-306.

Krieglsteiner, L. (2002). Pilze im NSG Sippenauer Moor bei Saal a. d. Donau (südwestlich Regensburg). Regensburger Mykologische Schriften 10: 67-133.

Kukkonen, I. \& Timonen, T. (1979). Species of Ustilaginales, especially of the genus Anthracoidea, as tools in plant taxonomy. Symbolae Botanicae Upsalienses 22: 166-176.

Legon, N.W. \& Henrici, A. (2005). Checklist of the British and Irish Basidiomycota. Royal Botanic Gardens: Kew (+ updates available from https://basidiochecklist.science.kew.org/)

Lind, J. (1913). Danish fungi as represented in the herbarium of E. Rostrup. Gyldendalske Boghandel Nordisk Forlag, Copenhagen.

Liro, J.I. (1924) Die Ustilagineen Finnlands I. Annales Academiae Scientiarum Fennicae, Series A 17 ixviii and 1-636. (in German)

Lutz, M., Göker, M., Piątek, M., Kemler, M., Begerow, D. \& Oberwinkler, F. (2005). Anther smuts of Caryophyllaceae: molecular characters indicate host-dependent species delimitation. Mycological Progress 4: 225-238.

Nordin, M. (2015). Pinguicula alpina (fjälltätört) på Gotland: pollination och fortplantning [Pinguicula alpina (alpine butterwort) on the Swedish island of Gotland: pollination and reproduction]. Institutionen för Biologisk Grundutbildning, Uppsala Universitet. https://www.divaportal.org/smash/get/diva2:892403/FULLTEXT01.pdf (in Swedish with English summary).

Savile, D.B.O. (1954). The fungi as aids in the taxonomy of the flowering plants. Science 120: 583585.

Schellenberg, H.C. (1911). Die Brandpilze der Schweiz. Beiträge zur Kryptogamen Flora der Schweiz vol. 3 book 2. Druck und Verlag von K.J. Wyss, Bern. (in German).

Woods, R.G., Chater, A.O., Smith, P.A., Stringer, R.N. \& Evans, D.A. (2018). Smut and Allied Fungi of Wales. A Guide, Red Data List and Census Catalogue. A.O. Chater, Aberystwyth.

Ziegler, R., Lutz, M., Piątek, J. \& Piątek, M. (2018). Dismantling a complex of anther smuts (Microbotryum) on carnivorous plants in the genus Pinguicula. Mycologia 110: 361-374. doi: 10.1080/00275514.2018.1451697. 